\title{
Prevalence of $\mathrm{ABO}$ and $\mathrm{Rh}$ blood groups and their association with demographic and anthropometric factors in an Iranian population: Mashad study
}

Mohammad Andalibi, ${ }^{1,2}$ Zahra Dehnavi, ${ }^{1 *}$ Asma Afshari, ${ }^{*}$ Maryam Tayefi, ${ }^{3}$ Habibolah Esmaeili, ${ }^{4}$ Mahmoud Azarpazhooh, ${ }^{5}$ Mohsen Mouhebati, ${ }^{2}$ Mohsen Nematy, ${ }^{1}$ Alireza Heidari-Bakavoli, ${ }^{2}$ Maryam Shokri, ${ }^{1}$ Gordon Ferns, ${ }^{6}$ Majid Ghayour-Mobarhan ${ }^{2,3}$ and Mohammad Tayyebi ${ }^{2}$

${ }^{1}$ Department of Nutrition; ${ }^{2}$ Cardiovascular Research Center, Student Research Committee; ${ }^{3}$ Department of Modern Sciences and Technologies; ${ }^{4}$ Department of Biostatistics and Epidemiology, School of Health, Management and Social Determinants of Health Research Center, School of Medicine, Mashhad University of Medical Sciences, Mashhad, Islamic Republic of Iran (Correspondence to: Majid Ghayour-Mobarhan; Mohammad Tayyebi: Andalibims891@mums.ac.ir). ${ }^{5}$ Department of Clinical Neurological Science, University Hospital, London Health Science Center, University of Western Ontario, London, Canada. ${ }^{6}$ Brighton and Sussex Medical School, Division of Medical Education, Falmer, Brighton, United Kingdom.

\begin{abstract}
Background: Blood groups appear to be markers for various human diseases and their distribution among different communities, ethnic groups and geographical boundaries varies over time.

Aims: We aimed to investigate the frequency of $\mathrm{ABO}$ and Rh blood groups and their relationship with demographic and anthropometric characteristics among Iranian residents in Mashad

Methods: ABO and Rh blood groups were determined among 7268 participants from the MASHAD cohort study and their relationships with demographic and anthropometric parameters were evaluated. This part of the study was done in January 2017. Student t-test, ANOVA, Bonferroni' and Chi-squared were used for comparison of quantitative and qualitative variables.
\end{abstract}

Results: The most common blood group was O (33.8\%); AB was the least common (8.3\%). The prevalence of Rh-positive and Rh-negative was $88.2 \%$ and $11.8 \%$ respectively. There were statistically significant associations between $\mathrm{ABO}$ blood groups and demi-span $(P=0.03)$, even after correction for multiple comparisons.

Conclusion: Our findings showed there was no relationship between ABO blood groups and demographic characteristics although there was an association with anthropometric measurements such as demi-span.

Keywords: ABO blood group, Rh blood group, anthropometric parameters, Iran

Citation: Andalibi M; Dehnavi Z; Afshari A; Tayefi M; Esmaeili H; Azarpazhooh M et al. Prevalence of ABO and Rh blood groups and their association with demographic and anthropometric factors in an Iranian population: Mashad study. East Mediterr Health J. 2020;26(8):916-922. https://doi. org/10.26719/emhj.20.048

Received: 29/09/17; accepted: 12/05/18

Copyright @ World Health Organization (WHO) 2020. Open Access. Some rights reserved. This work is available under the CC BY-NC-SA 3.o IGO license (https://creativecommons.org/licenses/by-nc-sa/3.0/igo).

\section{Introduction}

The ABO and Rhesus (Rh) blood group systems are the most important among the 36 identified systems $(1,2)$. In the early 2oth century, 3 types of blood groups A, B and C (later re-named $\mathrm{O}$ ) were known and later the fourth group, $A B$, was discovered (3). The $A B O$ blood group antigens $(\mathrm{A}, \mathrm{B}$, and $\mathrm{H})$ are determined by carbohydrate molecules that are ordinarily considered as red blood cell antigens. They are also expressed on other human tissues such as vascular endothelium and epithelium, sensory neurons and platelets (4). The second most important blood group system is Rh, which was discovered in 1941 and includes only 2 phenotypes, Rh-positive and Rh-negative $(5,6)$.

Many studies have investigated the prevalence of $A B O$ and $\mathrm{Rh}$ blood groups in different populations and ethnic groups. These studies have been undertaken for several reasons: their importance in blood transfusion and organ transplantation, their application in genetic research, forensic pathology and anthropology and studying the ancestral relationships of human $(6,7)$. Blood group prevalence studies are also important in the management of blood product resources in the community as well as the assessment of different disorders related to blood groups, such as the risk of venous thromboembolism syndrome, blood coagulation and coronary artery disease (8).

Although the $\mathrm{ABO}$ blood group antigens are constant throughout life, the distribution of blood groups among different communities, ethnic groups and geographical boundaries do vary over time $(5,9)$, even within the same region (10). The ABO blood groups appear to be markers for various human diseases, including cardiovascular, neoplastic and infectious conditions (11). It has also been suggested that they are associated with certain personality characteristics $(12,13)$.

Hence, knowing the distribution of $\mathrm{ABO}$ and $\mathrm{Rh}$ blood groups within communities is important and helpful for safe blood transfusion and health care programmes (14). Several studies have reported the frequency of blood groups among Iranian people but till now only one has 
been carried out among people living in the north-eastern region of the Islamic Republic of Iran (15).

We aimed to determine the prevalence of blood groups and whether there was any relationship with demographic, socioeconomic and anthropometric characteristics among a representative sample population living in Mashhad, the capital of Khorasan-e Razavi province in the northeast of the country.

\section{Methods}

\section{Participants}

The study population comprised participants in the Mashad Cohort Study who were Iranian residents of Mashhad. This cohort was originally recruited in 2010 and will continue to be followed up until 2020 (16). Participants were selected using a stratified cluster random sampling technique. There were 3 strata from 3 regions in Mashhad including Mashhad health centres No. 1, 2 and 3. Each stratum was divided into 9 areas centred on Mashhad health care centre divisions (clusters). Families with members aged 35-65 years were identified. We excluded those with a history of stroke or peripheral and cardiovascular disease. Of the participants recruited into this cohort study, blood group was determined for 7268 of them.

All participants gave written informed consent prior to participation in this study, which was approved by the ethics committee of Mashhad University of Medical Sciences.

\section{Data collection}

This part of the study was carried out in January 2017Demographic and lifestyle characteristics, including age, sex, number of family members residing at the same location, educational attainment, job status and smoking habit, were collected via a questionnaire. Anthropometric parameters such as body mass index (BMI), demi-span (half the distance between their hands outstretched to either side in $\mathrm{cm}$ ), and waist and hip circumference were measured and recorded by a certified health care professional and a skilled nurse. Body weight was measured using a clinical scale to the nearest $0.5 \mathrm{~kg}$. Height was also measured without shoes to the nearest $\mathrm{cm}$ and BMI was calculated as weight $(\mathrm{kg}) / \mathrm{height}^{2}(\mathrm{~m})$.

Waist circumference was measured halfway between the lower border of the ribs and the iliac crest in a horizontal plane. Hip circumference was measured at the widest point over the buttocks with a flexible tape (17). Demi-span was also measured in triplicate, using a flexible tape. For quality control and reliability, we used preset tolerance limits, $0.2 \mathrm{~kg}$ for weight, and $0.5 \mathrm{~cm}$ for arm circumference.

Fasting blood samples were taken from the antecubital vein and transferred immediately to a tube containing $\operatorname{EDTA}(6)$.

\section{Determination of blood group}

The $\mathrm{ABO}$ and $\mathrm{Rh}$ blood groups were determined using the antigen-antibody agglutination test. The antisera were obtained from the plasma of each blood sample; 3 drops were taken, designated $\mathrm{A}, \mathrm{B}$ and $\mathrm{Rh}$, then the relevant antiserum (A, B and D) was added. The ABO blood groups were assessed based on agglutination using $A B O$ monoclonal reagents (Lorne, $\mathrm{UK}$ ) and for determination of Rh blood group Lo-Du1 and Lo-Du2 monoclonal reagents (Lorne, UK) (18).

\section{Statistical analysis}

All statistical analyses were performed using SPSS, version 16. Descriptive statistics were used to define baseline characteristics. Independent sample t-test, analysis of variance (ANOVA) and post hoc tests (Bonferroni) were used for comparison of quantitative variables in $\mathrm{Rh}$ and blood groups and the chi-squared test was used for comparing the distribution of qualitative variables in $\mathrm{Rh}$ and blood groups. A P-value of $<0.05$ was considered statistically significant.

\section{Results}

This study included 2882 males (39.6\%) and 4386 females $(60.3 \%)$ with a mean age of 48.1 [standard deviation (SD) 8.2] years. Among the 7268 participants, the most common blood group was $\mathrm{O}(n=2457,33.7 \%)$ and the least common was $\mathrm{AB}(n=599,8.2 \%)$ (Table 1$)$. The frequencies for Rh-positive and Rh-negative were $88.2 \%$ and $11.8 \%$ respectively.

A statistically significant difference was observed in the distribution of blood groups between the sexes ( $P$ $=0.02$ ) (Table 2). There was no statistically significant relationship between $\mathrm{ABO}$ blood groups and number of family members $(P=0.59)$ or educational attainment among individuals with different blood groups $(P=0.07)$ (Table 2).

Among our participants, $64.8 \%$ were unemployed or retired, $35.0 \%$ were employed and $0.1 \%$ were students; there was no statistically significant association between $\mathrm{ABO}$ blood group and job status $(P=0.23)$ (Table 2$)$. We also observed no significant association between $A B O$ blood group and smoking habit $(P=0.52)$.

\begin{tabular}{lcccccc}
\hline Table 1 Distribution of blood groups, Mashad, 2017 \\
Blood group & \multicolumn{2}{c}{ Males, } & \multicolumn{2}{c}{ Females, } & \multicolumn{2}{c}{ Total, } \\
& $\mathbf{n = 2 8 8 2}$ & \multicolumn{2}{c}{$\mathbf{n = 4 3 8 6}$} & \multicolumn{2}{c}{$\mathbf{n = 7 2 6 8}$} \\
& No. & $\%$ & No. & $\%$ & No. & $\%$ \\
\hline $\mathrm{A}$ & 869 & 30.2 & 1327 & 30.3 & 2196 & 30.2 \\
$\mathrm{~B}$ & 822 & 28.6 & 1194 & 27.2 & 2016 & 27.7 \\
$\mathrm{AB}$ & 204 & 7.1 & 395 & 9.0 & 599 & 8.3 \\
$\mathrm{O}$ & 987 & 34.2 & 1470 & 33.5 & 2457 & 33.8 \\
$\mathrm{Rh}+$ & 2543 & 88.2 & 3870 & 88.2 & 6413 & 88.2 \\
$\mathrm{Rh}-$ & 339 & 11.8 & 516 & 11.8 & 855 & 11.8 \\
\hline
\end{tabular}




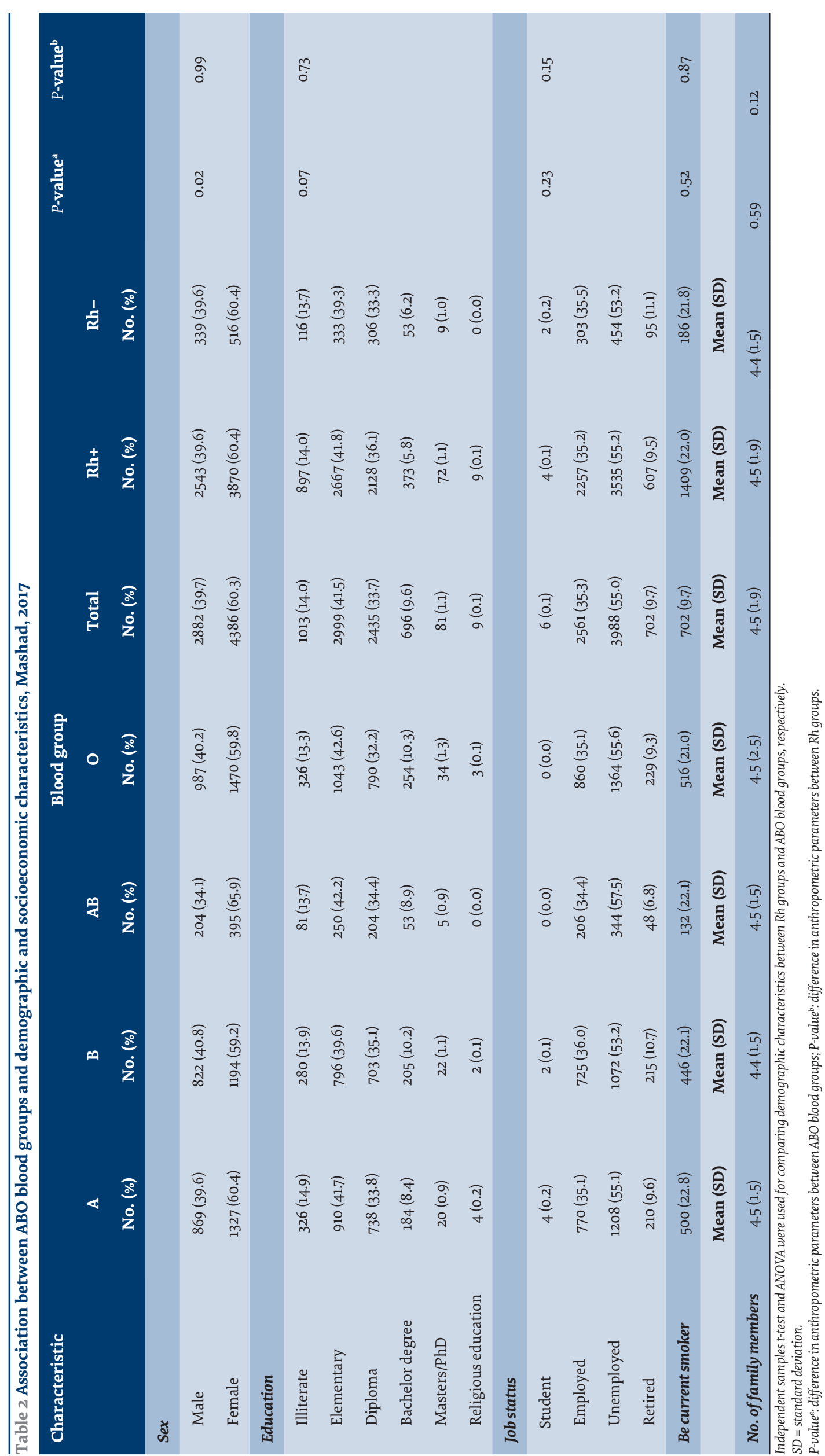




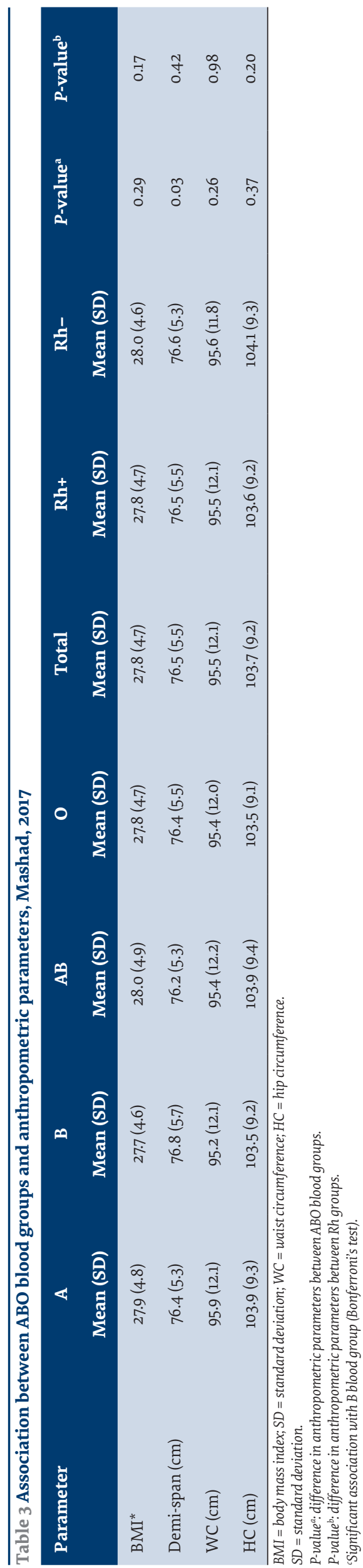

The mean demi-span was significantly higher among participants with blood group B (mean 76.7, SD 5.6) compared with the other participants $(P=0.03)$. The difference was greatest between blood groups $\mathrm{B}$ and $\mathrm{O}$ (76.7, SD 5.6 vs 76.3, SD 5.5) $(P=0.014)$, followed by $A B$ $(P=0.025)$ and $\mathrm{A}(P=0.032)$. There was no statistically significant difference between $\mathrm{ABO}$ blood groups and BMI $(P=0.3)$, waist circumference $(P=0.3)$ or hip circumference $(P=0.4)$ (Table 3 ).

\section{Discussion}

The $\mathrm{ABO}$ system comprises 4 groups, $\mathrm{A}, \mathrm{B}, \mathrm{AB}$ and $\mathrm{O}$, determined genetically by 3 allelic genes located on chromosome 9 (19). The distribution of blood groups varies regionally and ethnically and there have been a number of studies on the distribution of $\mathrm{ABO}$ and $\mathrm{Rh}$ blood groups in different geographical, ethnic and socioeconomic groups $(18,20)$.

Our findings in a population sample from Mashhad showed that blood group $\mathrm{O}$ had the highest frequency (33.7\%) and the frequency of $\mathrm{A}, \mathrm{B}$, and $\mathrm{AB}$ blood groups was $30.2 \%, 27.7 \%$, and $8.2 \%$ respectively. In 2 studies carried out in Pakistan and India, the most common blood group was $\mathrm{B}$, followed by $\mathrm{O}, \mathrm{A}$, and $\mathrm{AB}(6,18)$. In a study conducted in Saudi Arabia, the most prevalent blood group was $\mathrm{O}$, followed by $\mathrm{A}, \mathrm{B}$, and $\mathrm{AB}$ (7), comparable with our findings. In a population-based study from China, the most prevalent blood group was $\mathrm{A}$, followed by $\mathrm{O}, \mathrm{B}$ and $\mathrm{AB}$, and the frequency of $\mathrm{ABO}$ and $\mathrm{Rh}$ blood groups was significantly different among the ethnic groups in that study (21). In contrast, $\mathrm{O}$ was the most frequent blood group among our population. Data from British and American populations indicate that blood group $\mathrm{O}$ is the most common, followed by $\mathrm{A}, \mathrm{B}$, and $\mathrm{AB}$, which is in agreement with our study (22). Although these studies observed similar results to our own, other surveys carried out among the Iranian population from different regions and ethnicities showed some variations: the most common blood group was B in a study conducted in Yazd in 2007, and in a study conducted among the Azari population, the most common blood groups were A and $\mathrm{O}(1,23)$. These differences may reflect a difference in population genetics or migration at different times from different areas of the country.

In our study, the frequency of $A$ and $A B$ in females was greater than in males, while, the prevalence of $B$ and $\mathrm{O}$ was higher in males, indicating a possible difference of ethnic mix in the surveyed population. It should be noted that all of our study population were Iranian as self-declared, and this may be considered a limitation of this study; the ethnicity of the population should be more precisely determined.

In a 2004 study conducted among the population of Mashhad, the frequencies of $\mathrm{O}, \mathrm{A}, \mathrm{B}$ and $\mathrm{AB}$ blood groups in 867 individuals were recorded as $34.7 \%, 33.1 \%, 23.3 \%$ and $8.9 \%$, respectively, similar to our findings, however in that study there were no important differences in the frequency of $A B O$ blood groups based on sex (15). The 
smaller sample size (867 against 7268 in the current study) might have led to this difference.

The results of this and previous studies also showed that $A B$ was the least prevalent blood group, indicating that the gene segregation for the $\mathrm{ABO}$ system follows a similar a distribution pattern in various ethnic groups, with certain exceptions (10). In accordance with the different distribution of $\mathrm{ABO}$ blood groups, transfusion centres should consider different strategies for providing and storing blood products for the ongoing needs in the population. Moreover, different distributions of disorders which are associated with blood group would be expected in the community.

For the Rh system, the distribution pattern in different regions of the world and in the Islamic Republic of Iran is similar (20). In 1982, Porfathollah et al. reported that the Rh-positive and Rh-negative distribution was $89.62 \%$ and $10.38 \%$ respectively among the Iranian population (24). The frequency of Rh-positive in other parts of the world was also higher than the Rh-negative blood group as observed in the current study $(6,7,20)$. The $\mathrm{Rh}$ blood system distribution has remained constant over time.

Our findings showed no significant associations between demographic and socioeconomic factors and blood group; we also observed no significant relationship between the $\mathrm{ABO}$ blood groups and anthropometric parameters such as BMI, waist circumference and hip circumference. An exception was the significant association between demi-span and blood group $(P=0.03)$ : the prevalence was higher for group B in comparison with the other blood groups. Sirajuddin et al. observed a significant correlation between anthropometric factors and certain genetic factors such as ABO blood groups and the Rhesus antigen in an Indian population; however, they did not mention the anthropometric factors precisely (25). The results of a 2012 Iranian study showed that mean weight and BMI were significantly higher in those with blood group A compared with other blood groups, but mean height was not significantly different (26). In comparison, in our study, blood group $\mathrm{AB}$ individuals had slightly higher BMI values; a 1985 American study reported that B individuals were taller than non-B individuals (27).

\section{Conclusion}

In addition to the various distributions of the blood groups in different regions, blood group appears to be associated with anthropometric measures. Further longitudinal and multicentre studies are required to investigate the exact pattern and related factors of blood groups.

\section{Acknowledgement}

We are truly grateful to the 7268 community health volunteers for their major contribution to this study.

Funding: This study was supported by a grant from Mashhad University of Medical Sciences.

Competing interests: None declared.

\section{Prévalence des groupes sanguins $\mathrm{ABO}$ et $\mathrm{Rh}$ et leur association avec des facteurs démographiques et anthropométriques dans une tranche de la population iranienne : l'étude de MASHAD \\ Résumé}

Contexte : Les groupes sanguins semblent être des marqueurs de diverses maladies humaines. Leur répartition entre les différents groupes ethniques, communautés et frontières géographiques varie avec le temps.

Objectifs : Notre objectif était d'étudier la fréquence des groupes sanguins ABO et Rh et leur relation avec les caractéristiques démographiques et anthropométriques chez les habitants iraniens de Mashad

Méthodes : Les groupes sanguins ABO et Rh ont été déterminés chez les 7268 participants de l'étude de cohorte de MASHAD et leurs relations avec les paramètres démographiques et anthropométriques ont été évaluées. Cette partie de l'étude a été réalisée en janvier 2017. Le t-test de Student, l'analyse de la variance, l'ajustement de Bonferroni et le Chi carré ont été utilisés pour comparer les variables quantitatives et qualitatives.

Résultats : Le groupe sanguin le plus répandu était O (33,8\%); AB était le moins répandu (8,3 \%). La prévalence du rhésus positif et du rhésus négatif était de $88,2 \%$ et $11,8 \%$ respectivement. Il existe des associations statistiquement significatives entre les groupes sanguins $\mathrm{ABO}$ et la demi-envergure des bras $(p=0,03)$, même après correction pour les comparaisons multiples.

Conclusion : Les résultats de notre étude ont montré qu'il n'y avait pas de lien entre les groupes sanguins ABO et les caractéristiques démographiques; par contre, il existe une association avec des mesures anthropométriques telles que la demi-envergure des bras. 


\section{انتشار فصائل الدم ABO و Rh وارتباطها بالعوامل السكانية والقياسات الأنثروبومترية لدى الإيرانيين: دراسة \\ محمد الأندلبي، زهرة دهنوي، أسماء أفشاري، مريم طيفي، حبيب الله إسماعيلي، محمود ازاربازوح، محسن محباتي، محسن نماتي، علي رضا حيدري

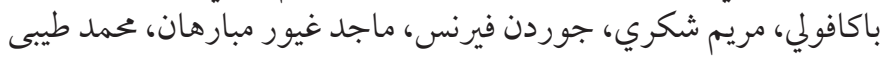

الخلفية: يبدو أن فصائل الدم علامات لأمر اض بشرية ختتلفة، ويختلف توزيعها بين المجتمعات المختلفة والمجموعات العرقية والحدود الجغغرافية بمرور الوقت.

الأهداف: هدفت هذه الدر اسة إلى استقصاء تو اتر فصائل الدم ABO و Rh وعلاقتها بالخصائص السكانية والقياسات الأنثروبومترية بين السكان الإيرانين في مدينة مشهد.

طرق البحث: حددت فصائل الدم ABO و Rh بين 268 و مشاركًا في الدراسة الأترابية (مشهد) وجرى تقييم لعلاقة فصائل الدم بالمتثابتات

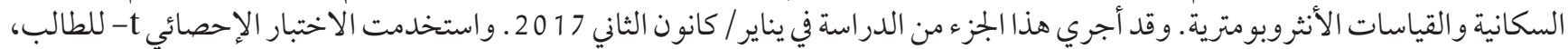

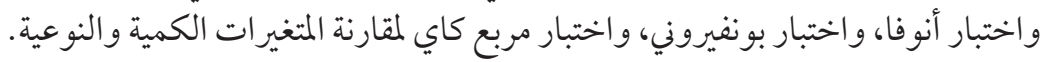

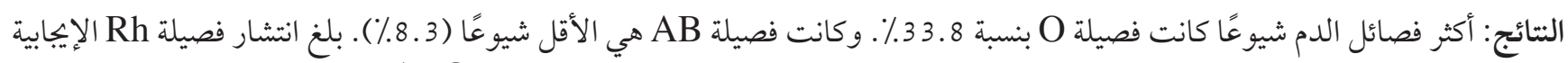

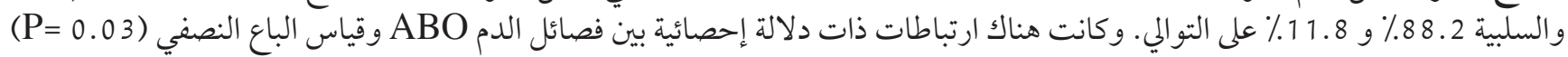
بعد التصويب لمقارنات متعددة.

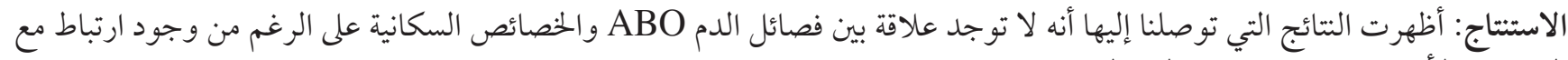

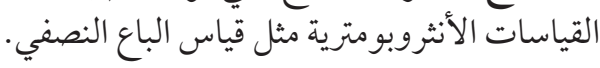

\section{References}

1. Ghasemi N, Ayatollahi J, Zadehrahmani M, Nasiri A, Abedi A, Shokraneh S, et al. Frequency of ABO and Rh blood groups in middle school students of Yazd province. Iran J Ped Hematol Oncol. 2010;1(1):27-30.

2. Storry JR, Castilho L, Chen Q, Daniels G, Denomme G, Flegel WA, et al. International society of blood transfusion working party on red cell immunogenetics and terminology: report of the Seoul and London meetings. ISBT Sci Ser. 2016 Aug;11(2):118-122. doi:10.1111/voxs.12280

3. D Farhud D, Yeganeh MZ. A brief history of human blood groups. Iran J Public Health. 2013;42(1):1-6. PMID:23514954

4. Gong P, Luo S-H, Li X-L, Guo Y-L, Zhu C-G, Xu R-X, et al. Relation of ABO blood groups to the severity of coronary atherosclerosis: an Gensini score assessment. Atherosclerosis. 2014 Dec;237(2):748-53. doi:10.1016/j.atherosclerosis.2014.10.107

5. Chandra T, Gupta A. Prevalence of ABO and rhesus blood groups in northern India. J Blood Disorders Transf. 2013;3(5):132-5. doi:10.4172/2155-9864.1000132

6. Shakir M, Khan SA, Ghani E. Frequency of ABO and Rh (D) blood groups among blood donors in Rawalpindi/Islamabad area. Pak Armed Forces Med J. 2012;62(2):59-64.

7. Sarhan MA, Saleh KA, Bin-Dajem SM. Distribution of ABO blood groups and rhesus factor in Southwest Saudi Arabia. Saudi Med J. 2009;30(1):116-9. PMID:19139784

8. Chung C, Wang R, Chen J, Fann C, Leu H, Ho H, et al. A genome-wide association study identifies new loci for ACE activity: potential implications for response to ACE inhibitor. Pharmacogenomics J. 2010;10(6):537-44. Pharmacogenomics J. 2010 Dec;10(6):537-44. doi:10.1038/tpj.2009.70

9. Chandra T, Gupta A. Association and distribution of hypertension, obesity and ABO blood groups in blood donors. Iran J Ped Hematol Oncol. 2012;2(4):140-5 PMID:24575254.

10. Tesfaye K, Petros Y, Andargie M. Frequency distribution of ABO and Rh (D) blood group alleles in Silte Zone, Ethiopia. Egypt J Med Hum Genet. 2015;16(1):71-6.

11. Liumbruno GM, Franchini M. Beyond immunohaematology: the role of the ABO blood group in human diseases. Blood TransM fus. 2013 Oct;11(4):491-9. doi:10.2450/2013.0152-13

12. Nahida A, Chatterjee N. A study on relationship between blood group and personality. Int J Home Sci. 2016;2(1):239-43.

13. Atoom MS. Blood groups and their relation with intelligence among a sample of Jordanian universities students. IJARER. 2014;2(8):178-85.

14. Patel Piyush A, Patel Sangeeta P, Shah Jigesh V, Oza Haren V. Frequency and distribution of blood groups in blood donors in western Ahmedabad-a hospital based study. Natl J Med Res. 2012;2(2):202-6. 
15. Boskabady M, Shademan A, Ghamami G, Mazloom R. Distribution of blood groups among population in the city of Mashhad (North East of Iran). Pak J Med Sci. 2005;21(2):194-8.

16. Ghayour-Mobarhan M, Moohebati M, Esmaily H, Ebrahimi M, Parizadeh SMR, Heidari-Bakavoli AR, et al. Mashhad stroke and heart atherosclerotic disorder (MASHAD) study: design, baseline characteristics and 10-year cardiovascular risk estimation. Int J Public Health. 2015 Jul;60(5):561-72. doi:10.1007/s00038-015-0679-6-72.

17. Subramanian V, Johnston R, Kaye P, Aithal G. Regional anthropometric measures associated with the severity of liver injury in patients with non $\nabla$ alcoholic fatty liver disease. Aliment Pharmacol Ther. 2013;37(4):455-63. Aliment Pharmacol Ther. 2013 Feb;37(4):455-63. doi:10.1111/apt.12198

18. Giri PA, Yadav S, Parhar GS, Phalke DB. Frequency of ABO and Rhesus blood groups: A study from a rural tertiary care teaching hospital in India. Int J Biol Med Res. 2011;2(4):988-90.

19. Eastlund T. The histo $\mathrm{Bblood}$ group ABO system and tissue transplantation. Transfusion (Paris). 1998;38(10):975-88. PMID:9767749

20. Ghobadian Z, Sayemiri K, Zeinali M, Sajjadi SM. Distribution of ABO and Rh blood groups in a major ethnic group of the West Iran, the Kurdish population. Asian J Med Sci. 2014;5(3):26-9.

21. Liu J, Zhang S, Wang Q, Shen H, Zhang Y, Liu M. Frequencies and ethnic distribution of ABO and RhD blood groups in China: a population-based cross-sectional study. BMJ Open. 2017 Dec 3;7(12):e018476. doi:10.1136/bmjopen-2017-018476

22. Adeyemo OA, Soboyejo OB. Frequency distribution of ABO, RH blood groups and blood genotypes among the cell biology and genetics students of University of Lagos, Nigeria. Afr J Biotechnol. 2006;5(22):2062-5. doi:10.4314/ajb.v5i22.55955

23. Nojavan M, Shamsasenjan K, Movassaghpour AA, Akbarzadehlaleh P, Torabi SE, Ghojazadeh M. Allelic prevalence of ABO blood group genes in Iranian Azari population. BioImpacts. 2012;2(4):207-12. doi:10.5681/bi.2012.016

24. Pourfathollah A, Oody A, Honarkaran N. Geographical distribution of ABO and Rh (D) blood groups among Iranian blood donors in the year 1361 (1982) as compared with that of the year 1380 (2001). Sci J Iran Blood Transfus Organ. 2004;1(1):11-7.

25. Sirajuddin S, Duggirala R, Crawford MH. Population structure of the Chenchu and other south Indian tribal groups: relationships between genetic, anthropometric, dermatoglyphic, geographic, and linguistic distances. Hum Biol. 1994;66(5):865-84. PMID:8001914

26. Jafari E, Sebghatollahi V, Kolahdoozan S, Elahi E, Pourshams A. body mass index and ABO blood groups among different ethnicities of the Golestan Cohort Study subjects. Govaresh. 2012;17(1):50-4.

27. Borecki I, Elston R, Rosenbaum P, Srinivasan S, Berenson G. ABO associations with blood pressure, serum lipids and lipoproteins, and anthropometric measures. Hum Hered. 1985;35(3):161-70. doi:10.1159/000153537 